\title{
Action Research in Teaching and Learning Strategies on English in India
}

\author{
Renuka Shyam Narain ${ }^{1}$, Sunil K. Mishra²
}

\author{
${ }^{1}$ (Postgraduate) Researcher, School of Management studies, Indira Gandhi Open University, Delhi, India \\ ${ }^{2}$ ORCID: 0000-0003-1582-6350 \\ Associate Professor of English,Amity University, Haryana, India
}

Received: 03 Jan 2021; Received in revised form: 15 Feb 2021; Accepted: 23 Feb 2021; Available online: 28 Feb 2021 (C)2021 The Author(s). Published by Infogain Publication. This is an open access article under the CC BY license (https://creativecommons.org/licenses/by/4.0/).

\begin{abstract}
India is a diverse country with diverse languages in different regions. People from different regions have different mother tongues. However, for education, English is a language that is preferred over others mainly to ensure that students do not face any problem in their professional life. Although for primary education, local languages are still preferred, however; in higher education, English has become the most important learning language (Mohanty, 2017). The recent trends in the increase of English medium schools in India show the fact that parents of the country are giving increasing importance on making their children get well skilled in English to get better jobs in future. English medium schools have not only built-in urban areas, in recent years, these schools are also being built in rural areas as well.
\end{abstract}

Keywords—English Language Teaching, Medium of Education, Higher education in India.

\section{INTRODUCTION}

The culture of English as a mode of learning mainly started in India from the British era. British rulers came in India and started to spread British culture in the education system of India. The main changes took place during the last few years of British era when many English medium schools started opening in the country (Sagayam, 2018). Although the British era ended in 1947, however, importance of English as a learning language increased year after year. However, there have been protests from many people regarding the intention of the Government to force the institutions to introduce English as a subject right from early primary education. This is mainly because; many people perceive that primary education should be completed in local languages and English should not be made mandatory.

In education system of India, usage of English mainly started from the British era and in recent years, demand of English in primary and secondary education has increased significantly.

This report will be based on evaluating the usage of English language in education system of India in the current years and in the past. This report will also evaluate the usage of English for teaching and learning in India in recent years. The focus will be to conduct the research in detail so that the primary purpose of this report is met successfully.

\section{TRENDS OF ENGLISH LANGUAGE IN THE EDUCATION SYSTEM OF INDIA}

In India, English has become an important language of communication in private companies, and it is a fact that candidates who are well skilled in English are generally preferred by companies over others. In this way, parents are giving importance on admitting their children in those schools that give importance on English education (Matthews, 2018). This thinking among Indians started in the British rule. In 1830s, Indian middle-class people began to realize that they will not be able to get Government jobs unless they become fluent in English. This is mainly because; at that time, British Government only recruited those Indians who could speak and write in English so that language barrier can be eliminated. Hence many private schools were set up in India especially in 
Calcutta and these schools-imposed English as the primary language for learning.

Raja Ram Mohan Roy also made efforts on modernizing the educational system of India and he wanted to make English as the mode of learning instead of Sanskrit or Persian language (Shastri, 2018). British rulers gave importance on implementing British culture in India so that they could easily communicate with Indians. English Literature was introduced as a subject in many secondary schools and universities. This started the era of English education in the educational system of India. Although after Independence, Hindi became the official language of India, however; Governments of many states insisted that English should be kept as a compulsory language for all students as it is a global language. Moreover, people gradually began to realize that without English skills, they will be not able to get any reputed jobs. Thus, the culture of English education grew among middle class and rich sections of people of the country and it increased year after year.

With the advancement of global technology and internet, importance of English language in the Indian education system increased. Educational institutes began to realize that they need to use English for teaching as it will help in better skill growth among students and students will be able to keep pace with global education (Chauhan, 2020). However, in some non-English medium schools of India, English education is introduced among students after $4^{\text {th }}$ or $5^{\text {th }}$ grade. This is mainly because; these skills want to keep local culture and language enacted among children. They realize that if English is introduced as a mode of learning, the students will not be able to give importance on their local language or mother tongue. However, the central Government of India has been making efforts on making English education mandatory right from early education to ensure that students do not face problems later in their academics while learning English.

Earlier one key issue was regarding availability of enough number of teachers who are skilled in English. However, with more people of India getting skilled in English, this scarcity is gradually reducing in the country. Hence, importance of English language in education is rapidly increasing in India. Nowadays many non-English medium schools have also introduced English right from the $1^{\text {st }}$ grade (Pandit, n.p.). English has become the most important language of learning in India and people who are not well skilled in English are considered as uneducated even if they have completed higher studies. They also do not get the scope to get high-salaried job or in reputed companies in India. Thus, changing perception of the society of India has brought in significant importance of English in the educational system of the country.

\section{ENGLISH AS A LANGUAGE OF TEACHING IN INDIA}

With the increasing number of English medium and with the non-English medium schools of India giving importance on having English as a mandatory subject, it has become necessary for teachers of the country to be efficient in English. Nowadays; individuals who are fluent in English get more scope to become a teacher that those who are not fluent. Earlier in India, teachers were required to be fluent in Sanskrit and other local languages as per their regions. Currently, English is the most important language that is used for selecting teachers for primary and secondary education in the country (Lavakare, 2018). However, except Meghalaya and Nagaland, in other states of the country, English is considered as the secondary language of education. The only exception is in the English medium schools, where English is treated as the primary language and all the subjects leaving aside Hindi and some local languages are taught in English. Thus, it is mandatory for teachers at English medium schools of India to be skilled in English.

By being well skilled in English, it becomes possible for teachers in India to help their students engaged in global study and to access global research papers and books. In universities, English has become a must language of teaching and it is not possible for individuals to become teachers without knowledge of English. This is exceptional only in cases of those individuals who apply for teaching in Hindi, Sanskrit, and some local languages. Thus, English is the most important used in India for teaching. English is also gradually becoming the most important language for teachers in India to teach students efficiently (Rao, n.p.). One of the issues that many aged teachers of India face is that when they were students, English was introduced a lot late in their academics. Moreover, many schools earlier did not give importance on English education. Hence, these aged teachers face problems on using English as a language to teach their students. However, in case of young teachers of India, this problem is less as they are well skilled in English.

Another problem that teachers face in India is that the educational system has not defined any standard of English for teaching or learning. Although British English is mainly used in India for all purpose, however; while using English as a mode of teaching, teachers of the country often face problems as English is not limited to British. Many English books adhere to US English as well. However, this is only a minor problem that teachers of 
India face. Overall, English has become almost a mandatory mode of teaching in India and thus, individuals of the country who aim to become teachers in future need to be well skilled in English right from their academic life (Lakshmi, n.p.). Hence, there have been significant changes in terms of teaching in English in India that started with the era of British rule in the country.

\section{ENGLISH AS A LANGUAGE OF LEARNING IN INDIA}

In India, English has become an important language for learning. This is evident from the fact that in most schools, English is either used as primary subjects or secondary subjects. The situation is not like 50 years ago, when many schools did not give importance on introducing English in their curriculum. As globalization has increased, hence; it has become necessary for schools and universities of India to keep English as a mandatory subject in their curriculum. Hence, students of the country now required to be efficient in English so that they would not face any issue in the professional life in future (Bhaskaran, 2017). Many middle class and rich families of the country have now become more inclined towards admitting their children in English medium schools so that their children can become more efficient in English. However, as the Government of India and Governments of states is giving importance on using English as a secondary subject in non-English medium schools,

These are the reasons students of India now have more scopes to learn English and to be efficient in this language. Nowadays many non-English medium schools have also introduced English right from the $1^{\text {st }}$ grade. English has become the most important language of learning in India and people who are not well skilled in English are considered as uneducated even if they have completed higher studies (Nedugandi, Mulki \& Raman, 2018). They also do not get the scope to get high-salaried job or in reputed companies in India. Students of the country thus now have become aware of the need of learning skill and hence, they are also giving importance to learn this language efficiently.

Many students after completing their higher studies go to Western countries like the United States for job. Many of them also leave India for higher studies. Hence, they are aware that if they do not get skilled in English, they would not get this scope. There are some challenges for students who live in rural areas. The challenge is that in many rural schools of India, there are limited numbers of teachers who are skilled in English. Moreover, many schools of rural areas also lack the facilities for students to learn English efficiently. If this challenge is solved, then it would become possible for all the students of this country to get equally skilled in English.

\section{NEGATIVE ASPECTS OF ENGLISH EDUCATION FOR INDIA}

One negative aspect of growth of English as a learning language in India is that many students are ignoring their own culture and mother tongue. Many people are there in India who finds it very difficult to speak or write in their mother tongue. Thus, demand of English language is hampering local languages of the country to some extent.

This is the main negative aspects, and this is the reason, many schools of the country are giving importance on teaching subjects in local languages along with English. The Government of India is also giving importance on this requirement so that local cultures and languages of India can be kept enact. Thus, it has become important to keep a balance between local languages of India and English for better learning outcomes for children. The recent trends in the increase of English medium schools in India show the fact that parents of the country are giving increasing importance on making their children get well skilled in English to get better jobs in future.

English medium schools have not only built-in urban areas, in recent years, these schools are also being built in rural areas as well. This growth in the numbers of English medium schools is posing threats for local languages of India. This is mainly because; with the increase in the number of English mediums, students of the country will not learn their local languages efficiently. Hence, it is also important for the English medium schools of India to ensure that along with English, local language should be also used in the curriculum for students. In this way, balance can be maintained as well (Mangal, 2020). Overall, English has enhanced academic growth of India as people of the country are now getting globalized with better employment opportunities. However, it is to be ensured that local languages are not hampered by any extent to maintain cultural elements of the country even in future. In this aspect, the local Governments and the central Governments of the country need to do future planning on properly utilizing English in the education system so that a proper balance can be maintained successfully currently and in future.

\section{CONCLUSION}

From the report, it has been identified that there has been a gradual change in the culture of English education in India. Before the start of the British rule, 
English was not relevant in the educational system as Sanskrit and Persian languages were used for education. However, British introduced the English learning culture in India and since then, importance of English in the education system of India has increased significantly. There are some challenges for teachers and students to utilize English in education. Those challenges have been evaluated in this report. Lastly, it has been evaluated that with the growth of English culture in the education system of India, there has been concern on the existence of local languages for learning. This challenge can be solved by maintaining a balance between English and other Indian languages in the educational system of India.

This report thus has been based on evaluating the usage of English language in education system of India in the current years and in the past. This report has also evaluated the usage of English for teaching and learning in India in recent years. The focus has been to conduct the research in detail so that the primary purpose of this report is met successfully. Overall, the goal of this report has been achieved.

\section{REFERENCES}

[1] Bhaskaran, R. P. (2017). Language complexity and multilingual education in India-A policy perspective.

[2] Chauhan, J. D. (2020). Higher Education in India-Issues, Challenges and Suggestions. High Educ. Retrieved from https://rrjournals. com/wp-content/uploads/2020/01/3336_RRIJM200501010. pdf.

[3] Lakshmi, A. R. GROWING DEMAND FOR ENGLISH LANGUAGE IN INDIA.

[4] Lavakare, P. J. (2018). India and China: Two major higher education hubs in Asia. International Higher Education, 94, 12-13.

[5] Mangal, A. (2020). A century of teacher education in India: 1883-1985. Espacio, Tiempo y Educación, 7(1), 263-285.

[6] Mathews, S. M. (2018). Language skills and secondary education in India. Economic and Political Weekly, 53(15), 20-22.

[7] Mohanty, A. (2017). Multilingualism, education, English and development: Whose development. Multilingualisms and development, 261-280.

[8] Nedungadi, P., Mulki, K., \& Raman, R. (2018). Improving educational outcomes \& reducing absenteeism at remote villages with mobile technology and WhatsAPP: Findings from rural India. Education and Information Technologies, 23(1), 113-127.

[9] Pandit, P. Contextual Presence of English in India. Bharatiya Manyaprad, 129.

[10] Rao, G. Comprehension in the English Classroom in India.

[11] Sagayam, S. (2018). A Significant Analysis on English Language Teaching in India. IJASSH.

[12] Shastri, A. (2018). Raja Ram Mohan Roy: The Great Emperor of Modern India. Anish Kumar Verma, 53. 